\title{
Online Learning During the COVID-19 Pandemic
}

\author{
I Putu Arya Dharmayasa ${ }^{1, *}$ Komang Krisna Heryanda ${ }^{2}$ Made Ary Meitriana $^{1}$
}

\author{
${ }^{1}$ Department of Economics and Accounting, Universitas Pendidikan Ganesha, Singaraja, Indonesia \\ ${ }^{2}$ Department of Management, Universitas Pendidikan Ganesha, Singaraja, Indonesia \\ *Corresponding author. Email: arya.dharmayasa@undiksha.ac.id
}

\begin{abstract}
This study aims to find student perceptions of online learning in terms of learning quality, suitability for learning levels, incentives in learning and timeliness in learning. The research was conducted in the Economics Education Study Program with a population of 246 students. The sampling technique used the slovin formula, so that the results obtained were 164 students who would be used as samples. Data collection in this study was carried out using a questionnaire. The results in this study indicate that $75.4 \%$ of respondents stated that the quality of learning was quite effective, $80.6 \%$ of respondents stated that the suitability of the learning level was in the very effective category, $79.7 \%$ of respondents stated that the incentives obtained by students were in the quite effective category, and $84,2 \%$ of respondents stated that the appropriateness of time in learning was in the very effective category. Overall, the perception of students in responding to learning during this pandemic is quite good and the students feel the benefits.
\end{abstract}

Keywords: Learning, Online, COVID-19.

\section{INTRODUCTION}

The purpose of education is in accordance with the 1945 Constitution as outlined in Law no. 20, 2003. Article 3 states, "In the context of educating the nation's life, national education serves to develop capabilities and shape the character and civilization of a dignified nation, with the goal of developing students' potential to become human beings who believe and fear God Almighty, have noble character, are healthy, knowledgeable, capable, creative, independent, and become democratic and responsible citizens.

Higher education is a place to educate students to have adequate intellectual abilities and skills as a provision for their lives in the future. With these intellectual abilities and skills, students are expected to become agents of change and community renewal. The Constitution of the State of Indonesia has mandated efforts to educate the nation's life. This shows that every school-age citizen from elementary to tertiary level must receive education. In fact, higher education has a very strategic role in preparing human resources to drive the nation's development. Superior human resources will encourage the nation's growth both in the fields of science, technology and the economic sector.

The importance of the role of universities should be balanced with the good process of the learning process provided to create graduates who have high competitiveness. In the classroom, learning is defined as the interaction between teachers and pupils. Reference [1] states that Learning is the process of students interacting with educators and learning materials in a learning environment where teachers and students are sharing knowledge. Learning and teaching activities are used to determine student achievement and attain educational goals in the teaching and learning process. Learning is the process of seeking one's knowledge by training, learning to change oneself.

The learning process is a system that involves various interrelated and interacting components [2]. Learning has the benefit of gaining knowledge and experience that can be developed [1].

Covid-19 (Corona Virus Disease 2019) emerged at the end of 2019 in Wuhan. The Covid-19 virus is a virus that transmits very quickly and is difficult to control. All countries have experienced the impact of Covid-19 and implemented a lockdown to anticipate the spread of Covid-19. Various sectors were paralyzed, initially the economic sector but with the increasing severity of Covid-19 the education sector was also paralyzed and almost all schools in various countries implemented SWH (School from Home). This is done with the aim of preventing the spread of COVID-19. UNESCO noted 
that around 188 countries in the world were affected by COVID-19.

The United Nations states that one of the sectors affected is the world of education [3]. In the education sector, around 1.5 billion students have been affected by COVID-19. The World Health Organization (WHO) recommends temporarily halting activities that would potentially create crowds. This is also regulated in the Joint Decree of the 4 Ministers that the learning process, especially at the higher education level in the odd semester of the 2020/2021 academic year in all zones, must be held online for theoretical subjects. Meanwhile, practical courses are also conducted online wherever possible. However, when it comes to graduation and student competencies that cannot be carried out online, these activities can be held while prioritizing the health and safety of students, lecturers and employees. The Covid-19 pandemic, which requires lecturers and students to carry out lecture activities from home, has made the distance learning system considered a solution to problems in carrying out learning. Distance education is a type of education in which students are separated from their teachers and are taught through a variety of learning resources such as communication technology, information, and other forms of media (Law number 20 of 2003 article 1 paragraph 15). Distance education (PJJ) is teaching students to learn independently and separately from educators and their learning using internet and online learning resources. Characteristics of distance education include: 1) There is a separation of learning that is close to a permanent element between teaching staff and students during the education program, 2) There is a separation between one student and other students during the education program, 3) There is an institution that manages distance education. education program. 4) Utilization of good mechanical communication facilities as learning materials, 5) Provision of two-way communication facilities so that students can take dialogue initiatives and seek and process the benefits [4].

When they have to conduct distant learning, problems occur, such as internet networks, infrastructure, and the production of online learning materials. Learning via the use of information technology, specifically the internet, in conjunction with tools to assist learning activities is referred to as online learning (Martins, 2015). Online learning is learning that is done without face-to-face and using a certain platform so that it can be done remotely. Online learning aims to provide learning services and a wider network [5]. Various applications for distance teaching and learning activities include, WhatsApp, zoom, web blog, Edmodo and others. Online learning has challenges in the expertise of using information technology from both educators and students.
The sudden condition made lecturers and students stutter in doing learning in class with virtual meetings. In distance learning there are several roles that must be considered including, 1) students in distance learning still need motivation, planning and the ability to analyze materials, assignments and tests independently. 2) the campus has a role as the success of the distance learning system such as providing infrastructure for lecturers to adapt teaching methods with the classroom system into technology-based learning. The existence of this kind of thing is very necessary to evaluate the learning that is being carried out. According to [6] the following four indicators can be used to assess the efficacy of learning: (1) The degree of information supplied to pupils so that they may easily acquire it or the error rate is growing reduced is the quality of learning (quality of insurance). The learning is more effective if the mistake rate is low. The mastery of particular instructional objectives, commonly referred to as learning completeness, is used to determine the efficacy of learning. The process and learning results are indicators of teaching quality. The appropriateness of instructor activities and student activities with the learning processes utilized is used to determine the learning process. According to [7] (1) The appropriate level of learning (appropriate level of instruction) is the extent to which the teacher ensures the level of readiness of students in accepting new material, namely KKM (Minimum Completeness Criteria); (2) the appropriate level of learning (appropriate level of instruction) is the extent to which the teacher ensures the level of readiness of students in accepting new material, namely KKM (Minimum Completeness Criteria); (3) the appropriate level of learning (appropriate level of instruction) is the extent to which the teacher ensure. The right level of teaching is said to be effective if students are ready to take part in learning, judging from the criteria for student learning readiness at least good. According to [8], Student preparedness is determined by three factors: (a) physical, mental, and emotional states; (b) needs, reasons, and objectives; and (c) learned skills, information, and other understandings. (3) Incentives are the measures through which a teacher's work stimulates students to finish or complete tasks and understand the topic. The more motivation supplied, the more active pupils will be, resulting in more effective learning. (4) The amount of time required to finish the learning activity is referred to as time. Students will learn more effectively if they can finish the session in the time given.

Almost the entire learning process has been impacted during this pandemic. Practical Learning is one of the learnings affected by Covid-19. Practical learning whose competence is to improve students' skills and competencies in using equipment, software and developing various projects. Practical learning is a learning activity that has a goal so that students can test 
and apply it in the laboratory and outside the laboratory [9]. Experiments are used to convey lessons in the practicum method. Students use practical tools when adopting this strategy, which includes regulating variables, observing, including comparisons or controls, and employing practical instruments. Students are given the chance to experience or do it themselves as part of the teaching and learning process with this practical technique. Students will be more confident in one thing than merely obtaining information from professors and books if they participate in practicums. They will gain valuable experience, build scientific attitudes, and their learning results will linger longer in their minds [10]. The practicum technique is a style of learning that involves direct practice in order to demonstrate a concept being learned [11].

Practical learning is ideally done offline, because of the pandemic, it must be done online. This is a problem in itself considering the uneven network infrastructure in various regions. Many students find it difficult to access. The emergency situation also made some lecturers carry out improvised online learning, only giving assignments, no interaction, difficulty creating digital content. From the problems above, the writer tries to find out the perception of students about the implementation of online practicum learning.

Universitas Pendidikan Ganesha, especially the Economics Education Study Program, also applies online learning for all courses, both practical and practical courses. Many facilities have been prepared by Universitas Pendidikan Ganesha to support the continuity of the learning process through several systems that have been developed. This sudden pandemic condition made almost all universities implement online learning suddenly as well. However, when online learning has been running for several semesters, it makes universities more mature in living this concept. Research conducted during the new pandemic period will definitely show bad results, but researchers want to do research when learning has been running for several semesters, so you can see how the progress is.

Several studies that have been carried out related to online learning are research on online learning in the midst of the Covid-19 outbreak which resulted in the conclusion that students have basic facilities to participate in learning and online learning fosters student independence in learning [12].

Online learning has been demonstrated to be less effective in other research. However, various supportive variables exist, such as the availability of mobile phones, quotas, and internet networks, while the hindering factor is the activity of parents at work, which prevents them from accompanying their children in online learning [13]. While research reference [5] shows that $69 \%$ of respondents stated that conventional learning was less effective, student interest in online learning was about $89 \%$ interested and $78 \%$ agreed that in its application it was considered more effective than conventional learning.

During the Covid-19 Pandemic, online learning was used as a Study from Home (SFH) effort that online learning done at home makes students more independent and creative in learning. Online learning is one of the things that supports the spread of Covid-19 [14].

The difference between the research that has been done and the research that the researcher is doing now lies in the indicators used as benchmarks. In addition to these indicators, the renewal of this research is also an added value, because actually researchers want to see how online learning is after a few semesters, is it still the same as previous research or has increased, both in terms of quality and so on.

\section{METHOD}

This study employed a descriptive technique with a quantitative approach as its research method. The fundamental objective of descriptive research is to describe or characterize phenomena based on empirical data that has been obtained via study to address challenges in the realm of education. [15].

The selection of the descriptive method in this study was based on the intent of the researcher who wanted to see and examine the perceptions of Economic Education students towards online learning during the pandemic.

This research was conducted at the Universitas Pendidikan Ganesha Economic Education Study Program, the subject in this study was online learning. The reason for doing research in the Economic Education Study Program is because this topic is still quite hot, not only in the Economics Education Study Program but for all Education personnel.

In this study, the object of research is the students of the Economic Education study program, Faculty of Economics, Universitas Pendidikan Ganesha, totaling 279 active students.

Sampling technique used slovin formula. Based on these calculations, the total sample of this study is 164 . The sample is used to represent the population as a source of data in the study. In choosing a sampling technique, the researcher uses a proportional random sampling technique, according to [16] "This proportional random sampling technique is used to take from each group in the population. This technique was chosen by the researchers in order to be able to represent the entire existing population, because the number of each population in each Force is different.

The quantitative research design was adopted in this investigation. The research design is the initial guideline 
for conducting research so that the research design must be specific, detailed, clear and determined from the start. The design of this research starts from the limitation of the problem in the formulation of the problem, the formulation of the problem is in the form of a question sentence, then the researcher uses various theories and sources to answer it. The researchers then employed a study instrument in the form of a questionnaire to collect data. Prior to conducting the research, the instrument was tested for validity and reliability in order to determine the level of validity and reliability of the instrument.

The data that has been collected is then analyzed and presented in tabular form and given a discussion. The discussion is an explanation of the data presented. After being explained in the discussion, the researcher concludes the research data and provides suggestions to solve the problem from the predetermined problem formulation.

\section{RESULTS \& DISCUSSION}

\subsection{Student Perceptions of Economic Education Study Program in terms of Learning Quality Indicators}

The perception of learning using online media for students of economic education study program in terms of learning quality indicators shows the following results.

Based on the results of the analysis in Table 1, it can be explained that the learning quality indicator obtained a score percentage of $75.4 \%$ which was in the perception ratio range of $60 \%-79.99 \%$, so it could be categorized as quite effective. This indicates that during online learning students do not have a good understanding. Learning resources used are still lacking. In addition, the concentration of students in participating in online learning is quite low. However, learning through online media can provide new experiences for students. In general, the perception of learning using online media for Economic Education study program students in terms of indicators of learning quality is quite effective.

\subsection{Student Perceptions of Economics Education Study Program in terms of Indicators of Appropriateness of Learning Level}

The perception of learning using online media on students of economic education study program in terms of indicators of suitability for learning levels shows the following results.

It may be deduced from the findings of the analysis in Table 2 that the learning level suitability indicator obtained a percentage score of $80.6 \%$ which was in the perception ratio range of $80 \%-100 \%$, so it could be categorized as very effective. This indicates that online learning in terms of the use of learning media is relatively easy and does not confuse students. The suitability of the learning resources used by the lecturer is in accordance with the material being taught. In addition, students easily access online media platforms so that students feel ready to take part in online learning. In general, the perception of learning using online media for students of the Economic Education study program in terms of the suitability indicator for the level of learning is very effective.

\subsection{Student Perceptions of Economic Education Study Program in terms of Incentive Indicators}

The perception of learning using online media on students of economic education study program in terms of incentive indicators shows the following results

Table 1. Results of Analysis of Student Perceptions of Economic Education Study Program in terms of Learning Quality Indicators

\begin{tabular}{|l|l|l|l|}
\hline Indicator & Score Percentage & Perception Ratio & Achievement Level \\
\hline Quality of learning & $75,4 \%$ & $60 \%-79,99 \%$ & Effective enough \\
\hline Total & $75,4 \%$ & $60 \%-79,99 \%$ & Effective enough \\
\hline
\end{tabular}

Table 2. Results of Data Analysis of Students' Perceptions of Economic Education Study Program in terms of Indicators of Suitability of Learning Levels

\begin{tabular}{|l|l|l|l|}
\hline Indicator & Score Percentage & Perception Ratio & Achievement Level \\
\hline Learning Level Suitability & $80,6 \%$ & $80 \%-100 \%$ & Very effective \\
\hline Total & $80,6 \%$ & $80 \%-100 \%$ & Very effective \\
\hline
\end{tabular}


Table 3. Results of Data Analysis of Learning Perceptions Using Online Media for Economic Education Study Program Students in terms of Incentive Indicators

\begin{tabular}{|l|l|l|c|}
\hline Indicator & Score Percentage & Perception Ratio & Achievement Level \\
\hline Incentive & $79,7 \%$ & $60 \%-79,99 \%$ & Effective enough \\
\hline Total & $79,7 \%$ & $60 \%-79,99 \%$ & Effective enough \\
\hline
\end{tabular}

Table 4. Results of Data Analysis of Learning Perceptions Using Online Media for Economic Education Study Program Students in terms of Time Indicators

\begin{tabular}{|l|l|l|l|}
\hline Indicator & Score Percentage & Perception Ratio & Achievement Level \\
\hline Time & $\mathbf{8 4 , 2} \%$ & $\mathbf{8 0 \% - 1 0 0 \%}$ & Very effective \\
\hline Total & $\mathbf{8 4 , 2} \%$ & $\mathbf{8 0} \%-\mathbf{1 0 0} \%$ & Very effective \\
\hline
\end{tabular}

Based on the results of the analysis in Table 3, it can be explained that the incentive indicator gets a score percentage of $79.7 \%$ which is in the perception ratio range of $60 \%-79.99 \%$, so it can be categorized as quite effective. This indicates that the internet quota assistance from the government for online learning has not been evenly received by students. There are still many students who have unstable internet connections so that online learning can be disrupted. In general, the perception of learning using online media for Economic Education study program students in terms of incentive indicators is quite effective.

\subsection{Student Perceptions of Economics Education Study Program in terms of Time Indicators}

The perception of learning using online media on economic education study program students in terms of time indicators shows the following result. Based on the results of the analysis in Table 4 , it can be explained that the time indicator obtains a percentage score of $84.2 \%$ which is in the perception ratio range of $80 \%$ $100 \%$, so it can be categorized as very effective. This indicates that students always submit assignments on time. Lecturers start and end lessons on time. Learning through online media can be done flexibly. The process of online learning activities is carried out according to the specified schedule. In general, the perception of learning using online media for Economic Education study program students in terms of time indicators is very effective.

\section{CONCLUSION}

Based on the results of the research above, what can be concluded in this study is that learning from the Undiksha economic education study program during this pandemic has been going well, this is due to maturity in carrying out learning. This can be seen from the four indicators used to measure how learning is in the moderate and very effective category. Although there are some obstacles, but with the passage of several years of online learning, students are used to it and have been able to prepare all preparations carefully before the learning process begins. Even though in the middle of the learning process, technical problems such as signal constraints were found.

\section{REFERENCES}

[1] Suyono and Hariyanto, Implementasi Belajar \& Pembelajaran. Bandung: Remaja Rosdakarya, 2015.

[2] A. Pane and M. Darwis Dasopang, "Belajar dan Pembelajaran," J. Kaji. Ilmu-Ilmu Keislam., vol. 3, no. 2, pp. 333-352, 2017.

[3] A. Purwanto et al., "Studi Eksploratif Dampak Pandemi COVID- 19 Terhadap Proses Pembelajaran Online di Sekolah Dasar," $J$. Educ. Psychol. Couns., vol. 2, no. 1, pp. 1-12, 2020.

[4] Warsito, "Peran TIK dalam Penyelenggaraan PJJ," J. Teknodik., vol. 20, pp. 9-41, 2007.

[5] Sofyana and Abdul, "Pembelajaran Daring Kombinasi Berbasis Whatsapp Pada Kelas Karyawan Prodi Teknik Informatika Universitas PGRI Madiun," J. Nas. Pendidik. Tek. Inform., vol. 8, no. 1, pp. 81-86, 2019.

[6] R. E. Slavin, Cooperative Learning, Teori, Riset, dan Praktek. Bandung: Nusa Media, 2015.

[7] Suryosubroto, Proses Belajar Mengajar di Sekolah. Jakarta: Rineka Cipta, 2009.

[8] Slameto, Belajar dan faktor-faktor yang Mempengaruhinya. Jakarta: PT. Rineka Cipta, 2010.

[9] N. Rustaman, Strategi Belajar Mengajar Biologi. Malang: UM Press, 2005.

[10] N. Khairun, "Penerapan Metode Praktikum Untuk Meningkatkan Hasil Belajar Siswa Pada Materi Fotosintesis Di Kelas VIII Mts 
Darul Amin Palangka Raya,” 2012.

[11] T. F. Zulfiani and K. Suartin, Strategi Pembelajaran Sains. Jakarta: UIN Syarif Hidayatullah, 2009.

[12] A. Sadikin and A. Hamidah, "Pembelajaran Daring di Tengah Wabah Covid-19.," J. Ilm. Pendidik. Biol., vol. 6, no. 2, pp. 214-224, 2020.

[13] H. Putria, L. H. Maula, and A. Din Uswatun, "Analisis Proses Pembelajaran Dalam Jaringan (DARING) Masa Pandemi COVID19 pada Guru Sekolah Dasar," J. Basicedu, vol. 4, no. 4, pp. 861-872, 2020.

[14] O. I. Handarini, "Pembelajaran Daring Sebagai Upaya Study From Home (SFH) Selama Pandemi Covid 19," J. Pendidik. Adm. Perkantoran, vol. 8, no. 3, pp. 496-503, 2020.

[15] M. Ali and M. Asrori, Metodologi dan Aplikasi Riset Pendidikan. Jakarta: Bumi Aksara, 2014.

[16] Sugiyono, Metode Penelitian Pendidikan Pendekatan Kuantitatif, Kualitatif, dan R\&D. Bandung: Alfabeta, 2014. 